\title{
Stable Magnetic Isotopes as a New Trend in Biomedicine
}

\author{
Vitaly K. Koltover \\ Institute of Problems of Chemical Physics, Russian Academy of Sciences, \\ Chernogolovka, Moscow Region, \\ Russian Federation
}

\section{Introduction}

Diverse organisms possess the ability to perceive Earth's magnetic field, the strength of which is about $0.05 \mathrm{mT}$ (Lohmann, 2010; Gould, 2010). There exist magnetotactic bacteria the ability of which to use geomagnetic fields for direction sensing is accomplished owing to the so-called magnetosomes, the specific nanometer-sized magnetite particles organized into chains within the cell (Komeili, 2007).

However, apart from external magnetic fields, another variety of natural magnetism is around, namely, magnetic fields of atomic nuclei of magnetic isotopes. Some of them produce intramolecular magnetic fields which are 10-100 times greater than terrestrial (Grant \& Harris, 1996). This raises the question of whether living cells can perceive the difference between magnetic and non-magnetic isotopes of the same chemical element. There is also a practical issue of whether the cell can take advantage of the magnetic isotopes.

The present article is a mini-review of the works of our group in this direction. The premises for our research have been the findings of magnetic-isotope effect (MIE) in chemical and biochemical physics within recent years (Brocklenhurst, 2002; Buchachenko, 2009). Following the concept of "nuclear spin catalysis in biopolymer nanoreactors" (Koltover, 2007, 2008), in experiments with bacteria Escherichia coli, the commonly accepted microbial model, we have revealed that the cells enriched with magnetic ${ }^{25} \mathrm{Mg}$ demonstrate essentially higher viability by comparison to the cells enriched with the nonmagnetic isotopes of magnesium (Bogatyrenko et al., 2009a, 2009b; Koltover et al., 2012). Furthermore, in experiments with Saccharomyces cerevisiae, another standard cell model, we have revealed

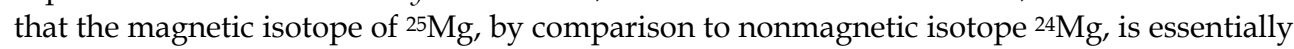
more effective stimulator of the recovery processes in the yeast cells after short-wave UV irradiation. The rate of post-radiation recovery was found to be twice as good for the cells enriched with ${ }^{25} \mathrm{Mg}$ as compared to the cells enriched with nonmagnetic isotope (Grodzinsky et al, 2011). Thus, the magnetic-isotope effects have been revealed, for the first time, in vivo. It opens up a new way in biomedicine, based on the stable magnetic isotopes, namely, the novel preventive medicine including new, ${ }^{25} \mathrm{Mg}$-based, anti-stress drugs as well as anti-aging and anti-radiation protectors. 


\section{Ab initio: Magnetic-isotope catalysis in chemistry and biochemistry}

Apart from the energy control (the law of conservation of energy), any chemical reaction as electron-nuclear rearrangement of reactants into products is controlled by angular momentum, spin, of reactants. Namely, the total spin of reaction products must be identical to the total spin of reactants. This law of spin conservation immediately follows from quantum mechanics, from the fundamental and universal Pauli principle: no two electrons may occupy the same quantum state simultaneously (see, e.g., Brocklenhurst, 2002; Buchachenko, 2009).

Figure 1 illustrates how the law of conservation of spin gives control over reactivity of free radicals, $R \cdot$. For example, a pair of free radicals, each with electron spin $S=1 / 2$, may form a chemical bond and the resultant diamagnetic molecule, the total electron spin of which $S=0$ (Fig. 1a). However, from the law of conservation of spin, it follows that the chemical bond between these two radicals may happen only if the spin state of the pair at collision is singlet, i.e., spins of two electrons are subtracted to give the net $S=0$ (spin multiplicity, $2 S+1=1$ ). If the spin state of the radical pair is triplet, i.e., if the electron spins are added up to give the net $S=1$ (spin multiplicity, $2 S+1=3$ ), then the radicals cannot react immediately.

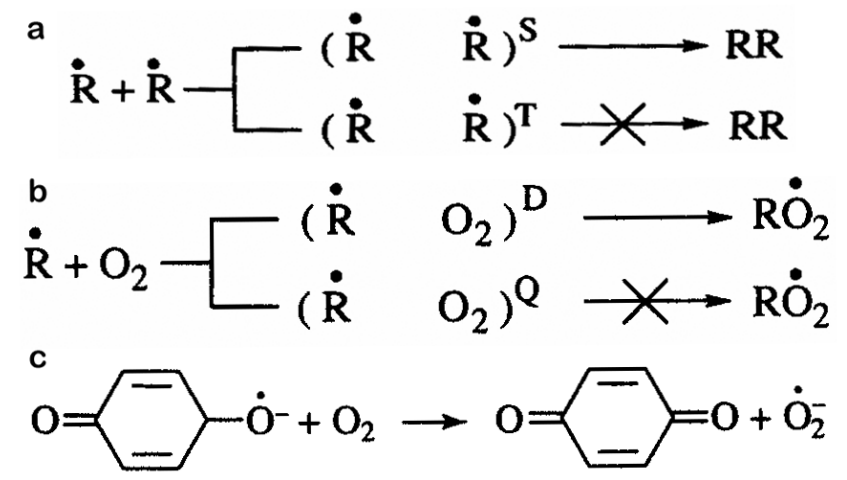

Fig. 1. Spin control in the chemical reactions of free-radical pairs.

In gas or liquid phase, with the time allotted for any collisions of radicals of order of $1 \mathrm{~ns}$ or less, neither spin-spin relaxation (in order of $10 \mathrm{~ns}$ ) nor spin-lattice relaxation (in order of $100 \mathrm{~ns}$ ) has time to fit the spin orientation. As a result, only one-quarter of encounters, with the radical pair in the singlet state, gives the recombination product while three-quarters of the initial radical pairs are inhibited from the reaction. Another example is presented on Fig. $1 b$. Namely, it is the reaction of free radical $R \cdot$ with oxygen, molecules of which are normally in the triplet spin state. The total spin, $S$, of this reagent pair can be $1 / 2$ when the individual spins are subtracted $(2 S+1=1)$ or $3 / 2$ when the individual spins are added up $(2 S+1=4)$. Meanwhile, for the product of the reaction $\mathrm{RO}_{2}{ }^{\circ}$, peroxyl radical, $S=1 / 2$. Hence, from six possible spin states of the reactants only two states do not require a change in the total electron spin of the reactants and, therefore, are permitted for formation of $\mathrm{RO}_{2} *$; other four states are forbidden for the reaction. A well-known reaction of mitochondrial ubisemiquinone with oxygen, in which $\mathrm{O}_{2}{ }^{--}$is produced, exhibits a similar case (see, e.g., (Chance, 1979; Nohl et al., 1993). This reaction is permitted only from the doublet state of the 
reactants. Four quartet "channels" are forbidden by the law of the spin conservation (Fig. 1c).

To lift the ban on reactions forced by the law of spin conservation, spins of the reactants must be changed. Inasmuch as spin-orbital coupling is negligibly small in organic free radicals, magnetic fields are the only means which are able to change the spin states and, thereby, switch the reaction over spin-forbidden and spin-allowed channels. The probability of chemical reaction is a function of the parameters of magnetic interactions (Brocklenhurst, 2002; Buchachenko, 2009):

$$
P=f\left(H ; \omega ; H_{1} ; J ; a ; m_{1} ; \mu_{n}\right)
$$

In this equation $H$ is external magnetic field (Zeeman interaction), $\omega$ and $H_{1}$ are frequency and amplitude of microwave magnetic fields. Correspondingly, acceleration of the freeradical reaction can be achieved through changes in the total electron spin of reactants by interaction with an applied external magnetic field. The parameter $J$ is energy of the exchange interaction. Correspondingly, the reactions of organic free radicals or ion-radicals can be catalyzed via interaction of partners of the radical pair with a foreign, third spin carrier, like nitroxide radical. It is called "electron spin catalysis".

The above mentioned equation also contains parameters of hyperfine coupling $a$, nuclear spin $I$, nuclear spin projection $m_{\mathrm{I}}$, and nuclear magnetic moment $\mu_{\mathrm{n}}$, i.e., the parameters of interactions of electron spins with magnetic nuclei which are known as the cause of the hyperfine splitting in EPR spectra of free radicals. Correspondingly, acceleration of the freeradical reactions can be achieved through changes in the total electron spin of reactants by interaction with magnetic fields of magnetic nuclei. This is known as "magnetic-isotope effect" (MIE): the reaction shows different reaction rates and different yields of products according to whether the reagents contain magnetic or nonmagnetic isotopes (Brocklenhurst, 2002; Buchachenko, 2009). While classical isotope mass effect selects isotopic nuclei in accordance with their masses, MIE selects isotopes by spin and magnetic moment. In action, MIE is a purely kinetic phenomenon and manifests itself as the dependence of the reaction rate on the nuclear spins of the reactants. Within recent years, MIE in chemistry has been discovered for a number of magnetic isotopes, among them $\mathrm{H}-\mathrm{D},{ }^{13} \mathrm{C},{ }^{17} \mathrm{O},{ }^{29} \mathrm{Si},{ }^{33} \mathrm{~S}$, ${ }^{73} \mathrm{Ge}, 117,119 \mathrm{Sn}, 199,201 \mathrm{Hg}$, and $235 \mathrm{U}$ (Buchachenko, 2009). By analogy with "electron spin catalysis", the enhancement of the reaction rate by the nuclear spins of the reactants can be denoted as the "nuclear spin catalysis" (Koltover, 2007, 2008).

In biochemistry, MIE has been recently discovered for magnetic isotope of magnesium, ${ }^{25} \mathrm{Mg}$, by A.L. Buchachenko and his group. It is generally known that energetic demands of every operation in living systems are met by molecules of ATP, be it eukaryotic cells of animals and plants or prokaryotic cells of bacteria. In aerobic organisms, most of ATP is produced in the so-called "oxidative phosphorylation". There are specific enzymes, "biomolecular nanoreactors", organized in the respiratory electron transport chains (ETC). Normal function of the ETC enzymes, be it mitochondrial nanoreactors in eukaryotic cells of animals or similar nanoreactors of bacteria cells, is in the transport of electrons, one by one, from the electron donor molecules to the end enzyme, cytochrome oxidase, from which the electrons are transferred to molecules of oxygen with two electron reduction of oxygen into water. Free energy released during the electron transport is used by the specific enzyme, 
ATP-synthase, for synthesis of ATP from adenosine 5'-diphosphate (ADP) and inorganic phosphate (Nelson \& Cox, 2008).

In the experiments with mitochondria isolated from the rat hearts, it has been revealed that the rate of oxidative phosphorylation with magnetic ${ }^{25} \mathrm{Mg}$ was $2-3$ times higher than that with nonmagnetic ${ }^{24} \mathrm{Mg}$ and ${ }^{26} \mathrm{Mg}$ while no difference was found between the nonmagnetic magnesium nuclei (Buchachenko et al., 2005). It was also revealed that activity of phosphocreatine kinase and phosphoglycerate kinase, for which ions of $\mathrm{Mg}^{2+}$ serve obligatory cofactors, was essentially higher with magnetic ${ }^{25} \mathrm{Mg}$ than with ${ }^{24} \mathrm{Mg}$ and ${ }^{26} \mathrm{Mg}$. Again, no difference in efficiency between the nonmagnetic magnesium nuclei was found in these experiments. Thus, there have been the very first evidences of MIE in biochemical reactions in vitro. Furthermore, the same research group has discovered MIE of calcium. The activity of phosphocreatine kinase with $\mathrm{Ca}^{2+}$ ions of magnetic nuclei ${ }^{43} \mathrm{Ca}$ was found to be twice higher than with $\mathrm{Ca}^{2+}$ ions of nonmagnetic nuclei ${ }^{40} \mathrm{Ca}$ (Buchachenko et al., 2011).

Factual evidence of MIE, on its own, indicates that there is a spin-selective "bottle-neck" of the process under investigation. The hypothetic mechanism of the acceleration of oxidative

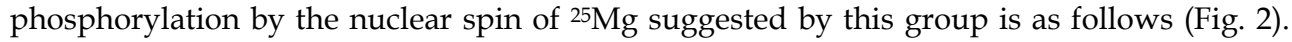
Namely, they suggested a reversible transfer of electron density in the active center of ATPsynthase from the terminal anion phosphate group of ADP to $\mathrm{Mg}^{2+}$-cation. It produces a virtual ion-radical pair, $\mathrm{Mg}^{+}$-adenosine phosphate radical in the singlet spin state.

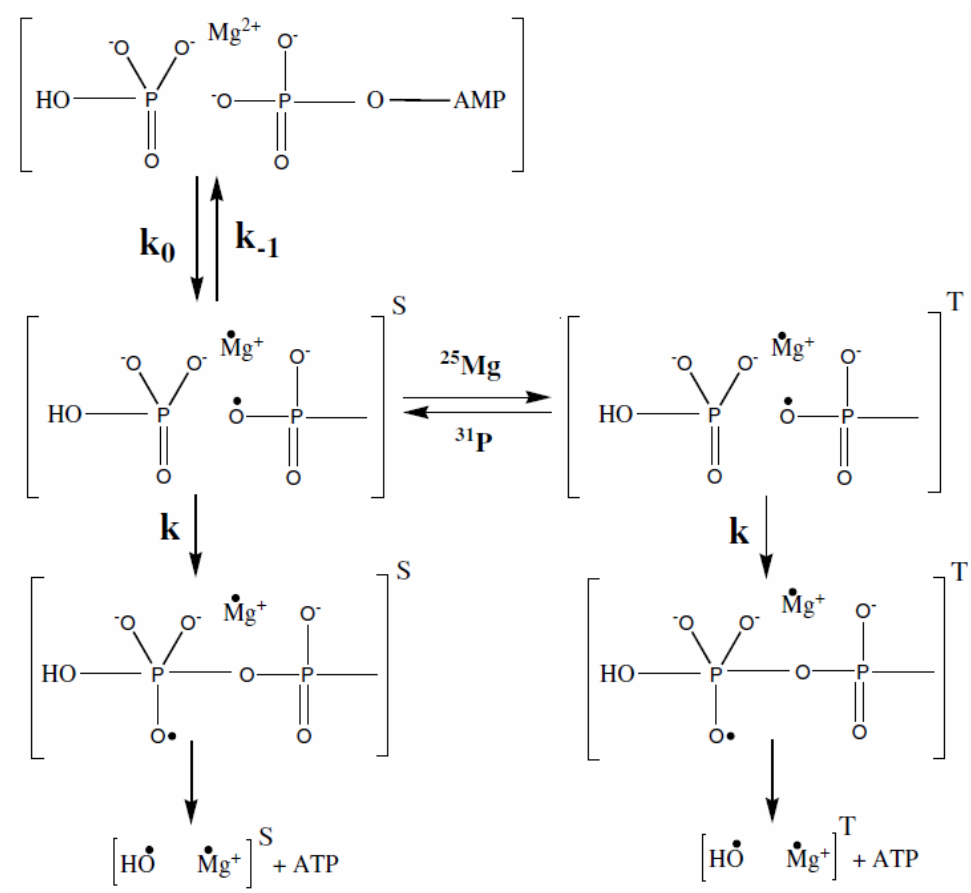

Fig. 2. Reaction scheme for enzymatic phosphorylation (Buchachenko et al., 2008). 
Due to the hyperfine interaction of the unpaired electron with the nuclear spin of $25 \mathrm{Mg}$, the state of this virtual pair is converted from the short-lived singlet (total electron spin of the pair, $S=0)$ into the long-lived triplet $(S=1)$ in which the yield of the reaction of the ATP synthesis correspondingly increases (Buchachenko et al., 2008). A similar spin-selective ionradical pair of $\mathrm{Ca}^{+}$with the phosphate radical of adenosine has been suggested to explain MIE of ${ }^{43} \mathrm{Ca}$ (Buchachenko, 2011).

It should be mentioned that the hypothesis about a possible key-role of such virtual ionradical pairs in oxidative phosphorylation and energy transformation processes has long been stated (Blumenfeld \& Koltover, 1972). Within the context of modern bioenergetics, which postulated a proton electrochemical gradient across the mitochondrial membrane as the energy-rich intermediate of oxidative phosphorylation in the "molecular motors" (see, e.g., Nelson \& Cox, 2008), another plausible explanation for the MIE can be proposed. It is reasonably to suggest that the proton electrochemical gradient poses conformational pressure in the catalytic center of ATP-synthase, generating electronic-conformational excitation in the ADP- $\mathrm{Mg}^{2+}$ complex. This would essentially increase reactivity of the adenine base of ADP to phosphate (Koltover et al., 1971; Blumenfeld \& Koltover, 1972). The nuclear spin of ${ }^{25} \mathrm{Mg}$ (or ${ }^{43} \mathrm{Ca}$ ) can provoke the transition of the exited ADP- $\mathrm{Mg}^{2+}$ complex from the singlet state to the triplet state the lifespan of which is longer, thereby providing more time for the reaction of the ATP synthesis from ADP and $P_{i}$. Thus, the detailed mechanism of the magnetic-isotope catalysis in bioenergetics remains to be cleared.

\section{In situ: Magnetic-isotope catalysis in living cells}

There is a great variety of chemical elements in biomolecular nanoreactors of living cells (see Table 1). Certain of them are only represented by magnetic isotopes, among them hydrogen, nitrogen, sodium, phosphorus, potassium, manganese and so on. However, there are chemical elements which have both kinds of stable isotopes, nonmagnetic and magnetic ones, among them - carbon, oxygen, magnesium, calcium, iron, zinc and others (Table 1). Correspondingly, these are the elements which are required to search for magnetic-isotope effects in living cells.

In this regard, magnesium is of particular interest. There are three stable isotopes of magnesium, ${ }^{24} \mathrm{Mg},{ }^{25} \mathrm{Mg}$ and ${ }^{26} \mathrm{Mg}$ with natural abundance about 79,10 and $11 \%$. Among them, only ${ }^{25 \mathrm{Mg}}$ has the nuclear spin $(I=5 / 2)$ that produces the magnetic field. Two other isotopes are spinless $(I=0)$ and, hence, produce no magnetic fields (Grant \& Harris, 1996). As the most abundant intracellular divalent cation, $\mathrm{Mg}^{2+}$ is essential to regulate numerous cellular functions and enzymes. Ions of $\mathrm{Mg}^{2+}$ serve as obligatory cofactors in catalytic centers of many enzymes including ATP-synthase as the primary producer of ATP in mitochondria, chloroplasts, bacteria and archaea (Nelson \& Cox, 2008). Moreover, a novel role for $\mathrm{Mg}^{2+}$ as an intracellular second messenger has been recently discovered ( $\mathrm{Li}$ et al., 2011). Besides, the difference in masses between the isotopes of magnesium is much less, in percentage term, than that for the isotopes of carbon, for example, thereby minimizing the classical mass-isotope effect.

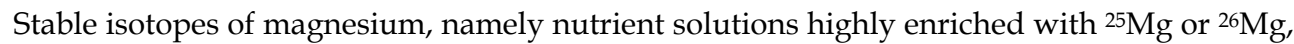
have been used for many years as in vivo tracers to determine magnesium absorption in human subjects, animals and plants models (see., e.g., Coudray et al., 2006; Weatherall et al., 2006). It is reasonable that the problem of possible beneficial effects of the magnetic isotope 


\begin{tabular}{|c|c|c|c|c|}
\hline Nucleus & $\begin{array}{l}\text { Natural } \\
\text { abundance, } \\
\text { in \% }\end{array}$ & $\begin{array}{l}\text { Nuclear } \\
\text { spin }(I) \text {, in } \\
\text { units of } \\
h / 2 \pi\end{array}$ & $\begin{array}{l}\text { Magnetic } \\
\text { moment }(\mu), \\
\text { in nuclear } \\
\text { magnetons } \\
(\text { eh } / 4 \pi M c)\end{array}$ & Biological functions \\
\hline $\begin{array}{l}{ }^{1} \mathrm{H} \\
{ }^{2} \mathrm{H}\end{array}$ & $\begin{array}{c}99.984 \\
0.016\end{array}$ & $\begin{array}{c}1 / 2 \\
1\end{array}$ & $\begin{array}{l}2.79270 \\
0.85738\end{array}$ & $\begin{array}{l}\text { Structure unit of water, biomolecules, } \\
\text { mitochondrial bioenergetics, etc. }\end{array}$ \\
\hline $\begin{array}{l}{ }^{12} \mathrm{C} \\
{ }^{13} \mathrm{C}\end{array}$ & $\begin{array}{c}98.89 \\
1.11\end{array}$ & $\begin{array}{c}0 \\
1 / 2\end{array}$ & $\begin{array}{c}0 \\
0.70216\end{array}$ & $\begin{array}{l}\text { Structure unit of biomolecules, } \\
\text { intracellular cation }\left(\mathrm{HCO}_{3}^{-}\right), \\
\text {extracellular buffer }\left(\mathrm{HCO}_{3}^{-} / \mathrm{H}_{2} \mathrm{CO}_{3}\right)\end{array}$ \\
\hline $\begin{array}{l}{ }^{14} \mathrm{~N} \\
{ }^{15} \mathrm{~N}\end{array}$ & $\begin{array}{c}99.635 \\
0.365\end{array}$ & $\begin{array}{c}1 \\
1 / 2\end{array}$ & $\begin{array}{c}0.40357 \\
-0.28304\end{array}$ & $\begin{array}{l}\text { Structure unit of amino acids, nucleic } \\
\text { acid, etc. }\end{array}$ \\
\hline $\begin{array}{l}16 \mathrm{O} \\
17 \mathrm{O} \\
18 \mathrm{O}\end{array}$ & $\begin{array}{c}99.759 \\
0.037 \\
0.204 \\
\end{array}$ & $\begin{array}{c}0 \\
5 / 2 \\
0\end{array}$ & $\begin{array}{c}0 \\
-0.18930 \\
0\end{array}$ & $\begin{array}{l}\text { Structure unit of water and } \\
\text { biomolecules, biological oxidation, } \\
\text { etc. }\end{array}$ \\
\hline${ }^{19} \mathrm{~F}$ & 100 & $1 / 2$ & 2.6273 & Structure unit of dental enamel \\
\hline${ }^{23} \mathrm{Na}$ & $100 \%$ & $3 / 2$ & 2.2161 & $\begin{array}{l}\text { Main extracellular cation, functional } \\
\text { unit of transmembrane } \\
\text { electrochemical potential, deposit } \\
\text { component of bond tissue, etc. }\end{array}$ \\
\hline $\begin{array}{l}{ }^{24} \mathrm{Mg} \\
{ }^{25} \mathrm{Mg} \\
{ }^{26} \mathrm{Mg}\end{array}$ & $\begin{array}{c}78.7 \\
10.13 \\
11.17\end{array}$ & $\begin{array}{c}0 \\
5 / 2 \\
0\end{array}$ & -0.85471 & $\begin{array}{l}\text { Main intracellular cation, structure } \\
\text { and functional unit of chlorophylls in } \\
\text { photosynthesis, obligatory cofactor of } \\
\mathrm{Mg}^{2+} \text {-dependent enzymes, including } \\
\text { oxidative phosphorylation, glycolysis, } \\
\text { synthesis of DNA and RNA, etc. }\end{array}$ \\
\hline $\begin{array}{l}28 \mathrm{Si} \\
{ }^{29} \mathrm{Si}\end{array}$ & $\begin{array}{c}92.21 \\
4.7\end{array}$ & $\begin{array}{c}0 \\
1 / 2\end{array}$ & -0.55477 & $\begin{array}{l}\text { Main structure unit of exoskeleton in } \\
\text { radiolarian and diatomic algae }\end{array}$ \\
\hline $31 \mathrm{P}$ & 100 & $1 / 2$ & 1.1305 & $\begin{array}{l}\text { ADP, } \mathrm{ATP}, \text { nucleic acids, } \\
\text { phospholipids, } \mathrm{P}_{\mathrm{i}} \text { as main anion, } \mathrm{P}_{\mathrm{i}} \text { as } \\
\text { regulator factor of transcription and } \\
\text { translation, etc. }\end{array}$ \\
\hline $\begin{array}{l}32 \mathrm{~S} \\
33 \mathrm{~S} \\
34 \mathrm{~S}\end{array}$ & $\begin{array}{c}95.02 \\
0.74 \\
4.22 \\
\end{array}$ & $\begin{array}{c}0 \\
3 / 2 \\
0\end{array}$ & 0.64274 & $\begin{array}{l}\text { Main intracellular anion }\left(\mathrm{SO}_{4}^{2-}\right), \\
\text { structure unit of cystine, cysteine and } \\
\text { methionine, and glutathione, etc. }\end{array}$ \\
\hline $\begin{array}{l}{ }^{35} \mathrm{Cl} \\
{ }^{37} \mathrm{Cl}\end{array}$ & $\begin{array}{l}75.4 \\
24.6\end{array}$ & $\begin{array}{l}3 / 2 \\
3 / 2\end{array}$ & $\begin{array}{l}0.82089 \\
0.68329\end{array}$ & Main intracellular anion \\
\hline $\begin{array}{l}{ }^{39} \mathrm{~K} \\
{ }^{41} \mathrm{~K}\end{array}$ & $\begin{array}{c}93.08 \\
6.91\end{array}$ & $\begin{array}{l}3 / 2 \\
3 / 2\end{array}$ & $\begin{array}{l}0.39094 \\
0.21453\end{array}$ & $\begin{array}{l}\text { Main intracellular cation, functional } \\
\text { unit of transmembrane } \\
\text { electrochemical potential, etc. }\end{array}$ \\
\hline $\begin{array}{l}{ }^{40} \mathrm{Ca} \\
{ }^{42} \mathrm{Ca} \\
{ }^{43} \mathrm{Ca} \\
{ }^{44} \mathrm{Ca} \\
{ }^{48} \mathrm{Ca}\end{array}$ & $\begin{array}{c}96.97 \\
0.64 \\
0.13 \\
2.06 \\
0.18\end{array}$ & $\begin{array}{c}0 \\
0 \\
7 / 2 \\
0 \\
0\end{array}$ & -1.3153 & $\begin{array}{l}\text { Main structure unit of bond tissue } \\
\left(\mathrm{Ca}_{3}\left(\mathrm{PO}_{4}\right)_{2}\right) \text {, regulator of membrane } \\
\text { ion channels, } \mathrm{Ca}^{2+} \text {-dependent myosin } \\
\text { and other ATPases, etc. }\end{array}$ \\
\hline
\end{tabular}




\begin{tabular}{|c|c|c|c|c|}
\hline Nucleus & $\begin{array}{l}\text { Natural } \\
\text { abundance, } \\
\text { in \% }\end{array}$ & $\begin{array}{l}\text { Nuclear } \\
\text { spin }(I) \text {, in } \\
\text { units of } \\
h / 2 \pi\end{array}$ & $\begin{array}{l}\text { Magnetic } \\
\text { moment }(\mu), \\
\text { in nuclear } \\
\text { magnetons } \\
(\text { eh } / 4 \pi M c) \\
\end{array}$ & Biological functions \\
\hline${ }^{55} \mathrm{Mn}$ & 100 & $5 / 2$ & 3.4610 & $\begin{array}{l}\text { Microbial Mn-superoxide dismutase, } \\
\text { glutamine synthase, rat liver pyruvate } \\
\text { carboxylase, etc. }\end{array}$ \\
\hline $\begin{array}{l}{ }^{54} \mathrm{Fe} \\
56 \mathrm{Fe} \\
57 \mathrm{Fe} \\
{ }^{58} \mathrm{Fe}\end{array}$ & $\begin{array}{c}5.82 \\
91.66 \\
2.245 \\
0.33 \\
\end{array}$ & $\begin{array}{c}0 \\
0 \\
1 / 2 \\
0 \\
\end{array}$ & $<0.05$ & $\begin{array}{l}\text { Heme- and non-heme proteins of } \\
\text { electron transport, Fe-superoxide } \\
\text { dismutase, etc. }\end{array}$ \\
\hline${ }^{59} \mathrm{Co}$ & 100 & $7 / 2$ & 4.6388 & $\begin{array}{l}\text { Vitamin } B_{12} \text {, biosynthesis of heme } \\
\text { proteins, etc. }\end{array}$ \\
\hline $\begin{array}{l}{ }^{63} \mathrm{Cu} \\
{ }^{55} \mathrm{Cu}\end{array}$ & $\begin{array}{l}69.09 \\
30.91\end{array}$ & $\begin{array}{l}3 / 2 \\
3 / 2\end{array}$ & $\begin{array}{l}2.2206 \\
2.3790\end{array}$ & $\begin{array}{l}\text { Cytochrome oxidase, } \mathrm{Cu}, \mathrm{Zn} \text { - } \\
\text { superoxide dismutase, ceruloplasmin, } \\
\text { laccase, ascorbate oxidase, } \\
\text { monoamine oxidase, etc. } \\
\end{array}$ \\
\hline $\begin{array}{l}64 \mathrm{Zn} \\
66 \mathrm{Zn} \\
67 \mathrm{Zn} \\
68 \mathrm{Zn}\end{array}$ & $\begin{array}{l}48.6 \\
27.9 \\
4.12 \\
18.8\end{array}$ & $\begin{array}{c}0 \\
0 \\
5 / 2 \\
0\end{array}$ & 0.8735 & $\begin{array}{l}\mathrm{Cu}, \mathrm{Zn} \text {-superoxide dismutase, DNA- } \\
\text { polymerase, carbonic anhydrase, } \\
\text { alcohol dehydrogenase, pyruvate } \\
\text { dehydrogenase, } \\
\text { pyruvate carboxylase, aldolase, etc. }\end{array}$ \\
\hline${ }^{75} \mathrm{As}$ & 100 & $3 / 2$ & 1.4349 & $\begin{array}{l}\text { Activator of glycerylaldehyde } \\
\text { phosphate dehydrogenase }\end{array}$ \\
\hline $\begin{array}{l}74 \mathrm{Se} \\
76 \mathrm{Se} \\
77 \mathrm{Se} \\
78 \mathrm{Se} \\
80 \mathrm{Se} \\
81 \mathrm{Se} \\
\end{array}$ & $\begin{array}{c}0.87 \\
9.02 \\
7.58 \\
23.52 \\
49.82 \\
9.19 \\
\end{array}$ & $\begin{array}{c}0 \\
0 \\
1 / 2 \\
0 \\
0 \\
0 \\
\end{array}$ & 0.5333 & $\begin{array}{l}\text { Structure-functional unit of } \\
\text { glutathione peroxidase }\end{array}$ \\
\hline $\begin{array}{l}{ }^{92} \mathrm{Mo} \\
{ }^{94} \mathrm{Mo} \\
{ }^{95} \mathrm{Mo} \\
{ }^{96} \mathrm{Mo} \\
{ }^{97} \mathrm{Mo} \\
{ }^{98} \mathrm{Mo} \\
{ }^{100} \mathrm{Mo}\end{array}$ & $\begin{array}{c}14.84 \\
9.25 \\
15.92 \\
16.68 \\
9.55 \\
24.13 \\
9.63\end{array}$ & $\begin{array}{c}0 \\
0 \\
5 / 2 \\
0 \\
5 / 2 \\
0 \\
0\end{array}$ & $\begin{array}{l}-0.9099 \\
-0.9290\end{array}$ & $\begin{array}{l}\text { Structure-functional unit of } \\
\text { flavoproteins, nitrogenase, nitrate } \\
\text { reductase, sulphite oxidase, xantine } \\
\text { oxidase, etc. }\end{array}$ \\
\hline 127I & 100 & $5 / 2$ & 2.7939 & $\begin{array}{l}\text { Structure-functional unit of thyroid } \\
\text { hormones }\end{array}$ \\
\hline
\end{tabular}

Table 1. Stable isotopes in biological systems.

was not posed in the cited papers. There have been attempts to use the non-radioactive isotopes to make the oxidative biomolecules more stable against free-radical oxidation. It was found that deuterated polyunsaturated fatty acids protect yeast cells against the toxic effects of lipid autoxidation products (Hill et al., 2011). Both natural isotopes of hydrogen, 
${ }^{1} \mathrm{H}$ and ${ }^{2} \mathrm{H}(\mathrm{D})$, are magnetic ones, but they have the twofold difference in masses. Consequently, the observed protection should be ascribed to the mass-isotope effect instead of the magnetic isotopy. In the in vitro study of cleavage of deuterated DNA by the hydroxyl radical, the value of the kinetic effect was found to be close to 2, just the mass-ratio of hydrogen and deuterium. Similar mass-isotopic effects are, presumably, anticipated for stable isotopes of nitrogen ${ }^{15} \mathrm{~N}$ versus ${ }^{14} \mathrm{~N}$ and for carbon ${ }^{13} \mathrm{C}$ that is $8 \%$ heavier than ${ }^{12} \mathrm{C}$ (Hill et al., 2011).

Recently, the smart methods of labeling of nematodes Caenorhabditis elegans, which are commonly used in gerontology, with ${ }^{13} \mathrm{C}$ and ${ }^{15} \mathrm{~N}$ have been developed by feeding the worms with heavy isotope-labeled Escherichia coli (Fredens et al., 2011; Larance et al., 2011). However, with regards to the ideas of using the stable isotopes and their mass-isotope effects to stabilize cells against free-radical oxidation and, thereby, improve the living conditions and even extend the lifespan, there are doubts if high amounts of ${ }^{13} \mathrm{C}$ and ${ }^{15} \mathrm{~N}$ in the numerous proteins, DNA, RNA, and other molecules of living cells will have, eventually, beneficial effects rather than harmful ones.

In searching beneficial isotope effects, including possible distinctions between the effects of magnetic and nonmagnetic isotopes, the very first step should be preparation of the cells enriched with different isotopes of magnesium. With this aim, we used bacteria $E$. coli, the commonly accepted cell model, and the growth media of the identical chemical composition with one exception, that they were supplemented with different isotopes of magnesium, magnetic ${ }^{25} \mathrm{Mg}$ and nonmagnetic ${ }^{24} \mathrm{Mg}$ or ${ }^{26} \mathrm{Mg}$, as ${ }^{25} \mathrm{MgSO}_{4},{ }^{24} \mathrm{MgSO}_{4}$ or ${ }^{26} \mathrm{MgSO}_{4}$ (Bogatyrenko et al., 2009a, 2009b; Koltover et al., 2012). The oxides of magnesium, ${ }^{24} \mathrm{MgO}$, ${ }^{25} \mathrm{MgO}$ and ${ }^{26} \mathrm{MgO}$, with isotope enrichment 99.9, 98.8 and 97.7 atom percent, correspondingly, were purchased from RosAtom, Russia. ${ }^{24} \mathrm{MgSO}_{4},{ }^{25} \mathrm{MgSO}_{4}$ and ${ }^{26} \mathrm{MgSO}_{4}$ were prepared from the relevant oxides by using a standard acidic treatment with analytically pure sulphuric acid.

The pioneering studies have been done in Institute of Problems of Chemical Physics, RAS. Bacteria E. coli, strain BB, were cultivated in accordance with the standard design on the artificial liquid minimal M9-media, composed from $8 \mathrm{~g}$ of glucose, $2 \mathrm{~g}$ of $\mathrm{NH}_{4} \mathrm{Cl}, 12 \mathrm{~g}$ of $\mathrm{Na}_{2} \mathrm{HPO}_{4}, 6 \mathrm{~g}$ of $\mathrm{K}_{2} \mathrm{HPO}_{4}, 1 \mathrm{~g}$ of $\mathrm{NaCl}$ in $750 \mathrm{ml}$ of distilled water and $250 \mathrm{ml}$ of tap water as the source of microelements. The growth media were supplemented with the isotopes of magnesium so that the final concentration of ${ }^{24} \mathrm{MgSO}_{4}$ or ${ }^{25} \mathrm{MgSO}_{4}$ was $2.2 \mathrm{mM}$ per liter of the media. Cells were grown aerobically at $37^{\circ} \mathrm{C}$ with shaking, harvested at the late growth ("stationary" phase at $\mathrm{OD}_{600}$ of about 0.5 ), and viability of the cells was tested as their ability to form colonies (colony-forming units, $\mathrm{CFU}$ ) on the solid nutrient $\mathrm{BCP}$ agar using standard Petri's dishes.

The experimental data are presented in Fig. 3. The striking effect of the magnetic isotope, ${ }^{25} \mathrm{Mg}$, has been detected when tallying up the colony forming units. The standard nutrient agar contains all components necessary for normal growth of cells, including magnesium. Nevertheless, the amount of CFU formed by the bacteria, which were previously grown on magnetic ${ }^{25} \mathrm{Mg}$, has turned out to be about 40 percent higher in comparison with the bacteria, which were previously grown on nonmagnetic ${ }^{24} \mathrm{Mg}$ (Fig. 3a). Thus, the cells which have been previously enriched with the magnetic isotope of magnesium demonstrate the essentially higher viability in comparison to the cells enriched with the nonmagnetic isotope. 
Another striking effect of the magnetic isotope of magnesium has been detected when measuring activity of superoxide dismutase (SOD), the main antioxidant enzyme of the cells. The cells enriched with ${ }^{25} \mathrm{Mg}$ demonstrate the reduced activity of SOD, about 40 percent, when compared to the cells enriched with ${ }^{24} \mathrm{Mg}$ (Fig. $3 \mathrm{~b}$ ). It is generally known that E. coli growing aerobically contain MnSOD and FeSOD (Imlay \& Fridovich, 1991; Nelson \& Cox, 2008). Inasmuch as the total SOD activity is normally adjusted to the intracellular level of $\mathrm{O}_{2} \bullet-$, the reduced level of SOD in the cells can be considered as evidence for lower production of $\mathrm{O}_{2}^{\bullet-}$ as the failure by-product of cell respiration.
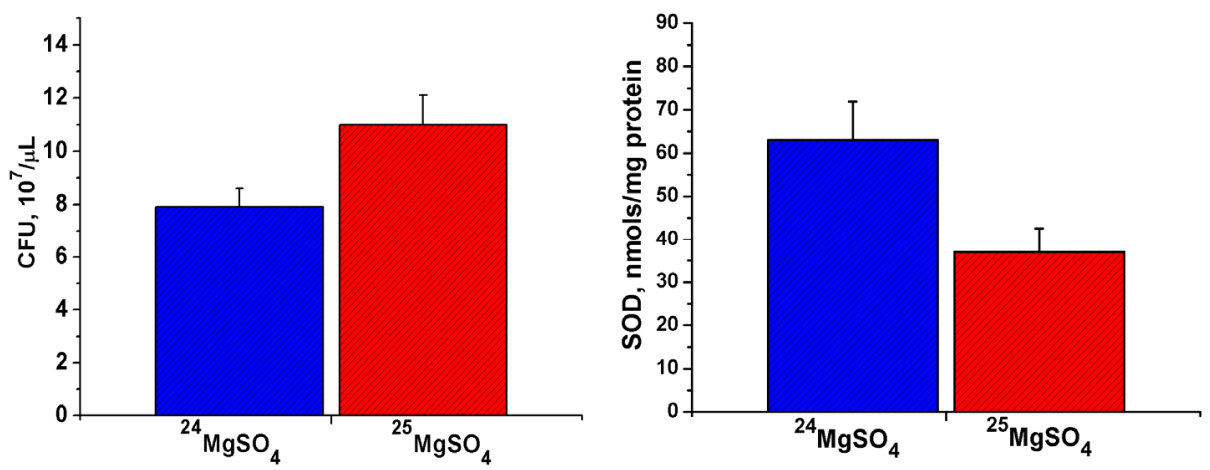

Fig. 3. The difference in effects of magnetic and nonmagnetic isotopes of magnesium on $E$. coli, strain BB (Bogatyrenko et al., 2009a). Left: ability of the cells enriched with magnetic ${ }^{25} \mathrm{Mg}$ or nonmagnetic ${ }^{24} \mathrm{Mg}$ to form colonies on the nutrition agar. Right: activity of superoxide dismutase in the cells enriched with magnetic ${ }^{25} \mathrm{Mg}$ or nonmagnetic ${ }^{24} \mathrm{Mg}$. Data are indicated as $m \pm S D, N=3$. The difference of the mean values $(m)$ for magnetic ${ }^{25} \mathrm{Mg} v s$. nonmagnetic ${ }^{24} \mathrm{Mg}$ is statistically significant at $P \leq 0.01$.

Thereafter, these experiments have been replicated in cooperation with the microbiologists of Orenburg State University using another strain of E. coli, K12TG1 (Koltover et al., 2012). After cultivation for $24 \mathrm{~h}$ in the artificial liquid minimal M9-medium without magnesium (and without tap water), the cells were suspended in the fresh M9-medium supplemented with different isotopes of magnesium as $0.26 \mathrm{~g}$ of ${ }^{24} \mathrm{MgSO}_{4},{ }^{25} \mathrm{MgSO}_{4}$ or ${ }^{26} \mathrm{MgSO}_{4}$ per liter, and grown aerobically at $37^{\circ} \mathrm{C}$. To obtain reproducible results, three parallel experiments with each kind of the isotopes have been simultaneously performed, i.e. bacteria supplied

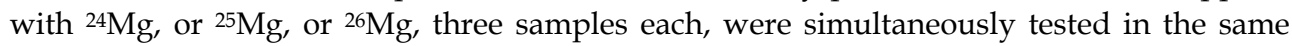
experimental succession. After reaching the stationary phase with $\mathrm{OD}_{620}$ of about 0.5 , the cells were tested for their ability to form colonies after inoculation on the agar plate's surfaces.

From the experimental results, shown on Fig. 4, one can see that the amount of CFU formed by the bacteria, previously grown on magnetic ${ }^{25} \mathrm{Mg}$, has turned out to be almost twice higher in comparison with the bacteria which were previously grown on nonmagnetic ${ }^{24} \mathrm{Mg}$ and ${ }^{26} \mathrm{Mg}$. Noteworthy, there has been no significant difference between nonmagnetic ${ }^{24 \mathrm{Mg}}$ and ${ }^{26 \mathrm{Mg}}$ in their effects on CFU. It gives evidence that there is the magnetic isotope effect of ${ }^{25 \mathrm{Mg}}$ rather than a classical mass-dependent isotope effect of the magnesium isotopes. 

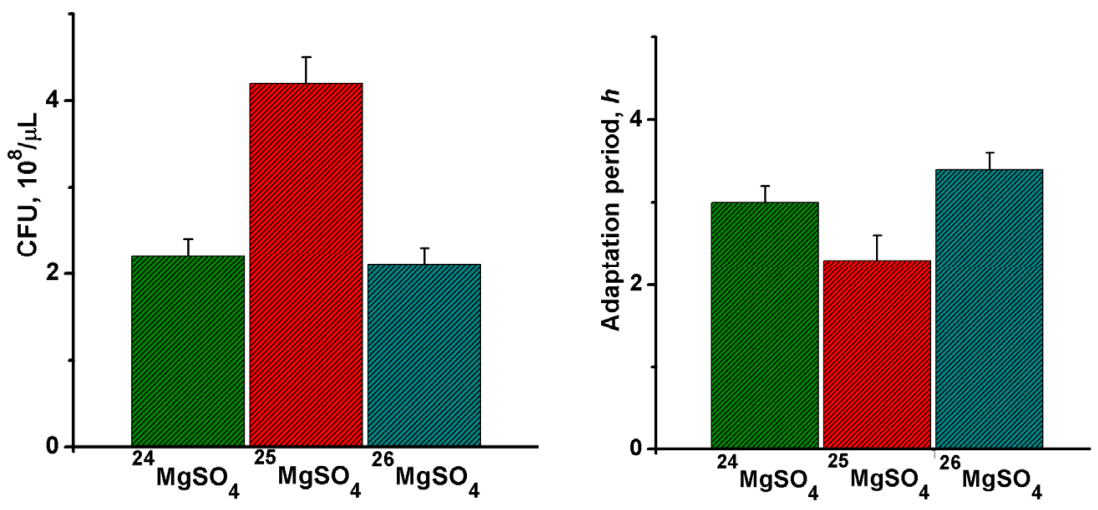

Fig. 4. The difference in effects of magnetic and nonmagnetic isotopes of magnesium on $E$. coli, strain K12TG1 (Koltover et al., 2012). Left: Ability of the cells enriched with magnetic ${ }^{25} \mathrm{Mg}$ or nonmagnetic ${ }^{24} \mathrm{Mg}$ and ${ }^{26} \mathrm{Mg}$ to form colonies on the nutrition agar. Data are $m \pm$ s.d., $N=3$. The differences of $m$ for magnetic ${ }^{25} \mathrm{Mg} v s$. nonmagnetic ${ }^{24} \mathrm{Mg}$ or ${ }^{26} \mathrm{Mg}$ are statistically significant at $\mathrm{P}<0.005$. Right: Length of adaptation period (lag-phase) on the liquid media supplemented with magnetic ${ }^{25} \mathrm{Mg}$ or nonmagnetic ${ }^{24} \mathrm{Mg}$ and ${ }^{26} \mathrm{Mg}$. Data are $m \pm$ s.d., $N=3$. The differences of $m$ for ${ }^{25} \mathrm{Mg} v s$. ${ }^{24} \mathrm{Mg}$ or ${ }^{26} \mathrm{Mg}$ are statistically significant at $\mathrm{P} \leq 0.02$.

In addition, kinetics of the cell growth was hourly monitored in the cited experiments, using optical density measurements at $620 \mathrm{~nm}$ with 96-cavity micro-plate reader "Uniplan" (Picon, Russia). The kinetic curves of cell biomass growth were typical for the bacterial growth involving slow adaptation period ("lag-phase") followed by exponential growth ("logphase") when the cell mass quickly doubled and the stationary phase when the cell growth completed because of lack of the substrates (primarily, glucose). The striking observation for these experiments was that length of the lag-phase has turned out to be essentially shorter in the case when the cells were transferred on the media with magnetic isotope of $25 \mathrm{Mg}$ in comparison with nonmagnetic ${ }^{24} \mathrm{Mg}$ and ${ }^{26} \mathrm{Mg}$ (Fig. $4 \mathrm{~b}$ ). Again, the nonmagnetic isotopes, ${ }^{24} \mathrm{Mg}$ and ${ }^{26} \mathrm{Mg}$, were not differentiated by their effects on the cell growth. It means that adaptation of cells transferred from the pre-incubation media is limited by some enzymatic processes, efficiency of which is increased by magnetic nuclei of ${ }^{25} \mathrm{Mg}$.

As it was cited above, magnetic isotope of ${ }^{25} \mathrm{Mg}$ more effectively performs the $\mathrm{Mg}^{2+}$ cofactor function for oxidative phosphorylation in the isolated mitochondria in comparison to ${ }^{24} \mathrm{Mg}$ or ${ }^{26} \mathrm{Mg}$ (Buchachenko et al., 2005). Energetic demands of every operation in prokaryotic cells of bacteria, as well as in eukaryotic cells of animals, are met by molecules of ATP. Hence, ATP as the main source of energy in living cells is most likely to be the limiting substrate for adaptation metabolism in the lag-phase. However, for the exponential phase of the cell growth, we have not found any significant differences in the rates of cell growth between magnetic ${ }^{25} \mathrm{Mg}$ and nonmagnetic ${ }^{24} \mathrm{Mg}$ and ${ }^{26} \mathrm{Mg}$. The time of doubling of the cell mass was approximately the same, regardless of the type of magnesium isotopes (Koltover et al., 2012). This obviously suggests a different "bottle-neck" of metabolism in the exponential phase of growth with other, than ATP, limiting substrate and another limiting reaction independent upon the nuclear spin of magnesium. 
Of special interest are searches for magnetic-isotope effects in the processes of recovery of cells from radiation injuries. The reason is that any factor, capable to influence on efficiency and reliability of cell nanoreactors, shows up itself most vividly under drastic conditions of post-radiation recovery (Koltover et al., 1980; Grodzinsky et al., 1987; Koltover, 1997).

We undertook the investigation of effects of magnetic and nonmagnetic isotopes of magnesium on post-radiation recovery of $S$. cerevisiae (Grodzinsky et al., 2011). The yeast cells (diploid strain MATa ade2 $\Delta 248$ leu2-3,112 ura3-160,188 trp1 $\Delta: \mathrm{kanr}$ ) were cultivated on the standard nutrient liquid media M3 supplemented with ${ }^{24} \mathrm{MgSO}_{4}$ or ${ }^{25} \mathrm{MgSO}_{4}$. After three days of the cultivation under aerobic conditions at $30^{\circ} \mathrm{C}$, the cells were washed from the nutrient liquid and suspended in nutrient-free ("fasting") media, i.e., sterile phosphate buffer, $\mathrm{pH}$ 7.0. Then, the cells were irradiated by the short-wave ultraviolet light $(\lambda \approx 240 \mathrm{~nm}$, the dose $\approx 190 \mathrm{~J} / \mathrm{m}^{2}$ ), whereupon they were left in the nutrient-free water at $30{ }^{\circ} \mathrm{C}$ (with shaking) to study kinetics of the post-radiation recovery of the cells. For this kinetics study, the aliquots of the cells were periodically seeded on the standard nutrient (Petri dishes) and the cell survival was monitored by the standard CFU technique.

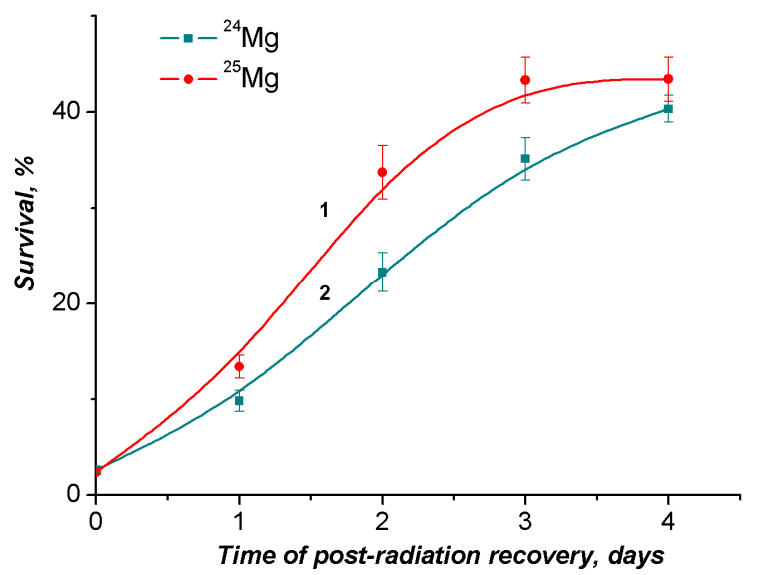

Fig. 5. The difference in effects of magnetic and nonmagnetic isotopes of magnesium on post-radiation recovery of $S$. cerevisiae, diploid yeast cells. The cells enriched with magnetic

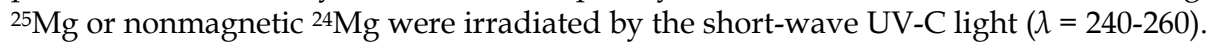
Survival of cells was estimated as their ability to form colonies on the nutrition agar: 1 - recovery of the cells enriched with ${ }^{25} \mathrm{Mg}$; 2 - recovery of the cells enriched with ${ }^{24} \mathrm{Mg}$ (Grodzinsky et al., 2011).

The survival of cells transferred to agar immediately after irradiation was not more than a few percent (Fig. 5). In this case the injured genetic structures in most of the cells could not be repaired before the onset of mitosis, and nonviable daughter cells were produced. Incubation in nutrient-free water, in which the cells do not divide, provides sufficient time for repair processes and leads to a corresponding increase in survival. From the kinetics curves represented on this figure we notice that the cells enriched with magnetic isotope of magnesium, ${ }^{25} \mathrm{Mg}$, are recovered essentially more effectively than the cell enriched with the nonmagnetic ${ }^{24} \mathrm{Mg}$. 
It has been known that kinetics of recovery of yeast cells from radiation injuries may be represented by a function representing the reduction of the effective radiation dose, $D_{\text {eff, }}$ with time:

$$
D_{\text {eff }}(t)=D_{o}[k+(1-k) \exp (-\beta t)]
$$

In this model of A. Novick and L. Szilard, $D_{0}$ is the radiation dose, $t$ is time of post-radiation recovery in the nutrient-free water, $\beta$ is the recovery rate constant, and $\kappa$ is the fraction of irreversible injuries (Grodzinsky et al., 1987; Koltover et al., 1980; Novick \& Szilard, 1949).

Table 2 represents values of the kinetics parameters resulting from these experiments. While the fraction of irreparable injuries remained almost the same, the value of the rate constant $\beta$ of the post-radiation recovery was twice higher for the cells enriched with ${ }^{25} \mathrm{Mg}$ than for the cells enriched with ${ }^{24} \mathrm{Mg}$. This is decisive evidence that the magnetic isotope of magnesium essentially more effectively promotes the recovery of cells from radiation damages. Thus, we have, for the first time, documented the magnetic-isotope effect in radiation biology (Grodzinsky et al., 2011).

\begin{tabular}{|c|c|c|}
\hline & $\beta, h^{-1}$ & $k$ \\
\hline${ }^{24} \mathrm{Mg}$ & $0.032 \pm 0.003$ & $0.70 \pm 0.14$ \\
\hline${ }^{25} \mathrm{Mg}$ & $0.058 \pm 0.004^{*}$ & $0.61 \pm 0.12$ \\
\hline
\end{tabular}

Table 2. Effect of magnetic ${ }^{25} \mathrm{Mg}$ isotope on postradiation recovery of $S$. cerevisiae, diploid yeast cells, after short wave UV irradiation. *Difference between the means is significant at $P=0.02$ (Grodzinsky et al., 2011).

One might suggest that the observed effects in our experiments with bacteria and yeast cells were caused by different levels of impurities in the growth media complemented with different isotopes of magnesium. However, it could hardly be the case. First, according to the mass-spectrometry data, amounts of contaminant elements in the stock solutions of the isotopes did not exceed $20-30 \mathrm{ppm}$, be it sulphate of ${ }^{24 \mathrm{Mg}},{ }^{25 \mathrm{Mg}}$, or ${ }^{26 \mathrm{Mg}}$. Second, amounts of the contaminants that were administered in the liquid growth media with glucose and other basic components have significantly exceeded amounts of the same contaminants administered with much less additions of the isotope stock solutions. Besides, the impurities that were administered into the growth media from the basic components, as well as the element contents of the solid nutrient agar media, were obviously the same in all experiments, independently of the magnesium isotopes. Hence, one can disregard impurities as a possible reason of higher efficiency of magnetic ${ }^{25} \mathrm{Mg}$ than that of nonmagnetic ${ }^{24} \mathrm{Mg}$ and ${ }^{26} \mathrm{Mg}$. It is apparent that the cells in the above cited experiments perceive the difference between magnetic and non-magnetic isotopes of magnesium, i.e., they perceive the nuclear spin's magnetic field of ${ }^{25} \mathrm{Mg}$.

\section{Future prospect: Nuclear spin as factor of reliability in cell nanoreactors}

Thus, our data have documented, for the first time, the magnetic-isotope effect of magnesium-25 in vivo. Factual evidence of MIE, on its own, indicates that there is a spinselective "bottle-neck" of the process under investigation. Ions of $\mathrm{Mg}^{2+}$ perform not only the cofactor functions in synthesis and hydrolysis of ATP. In addition, they have the impact on 
the structure-functional properties of RNA, RNA-polymerase, ribonuclease, and so on. Besides, there are the specialized proteins which regulate homeostasis and transport of $\mathrm{Mg}^{2+}$ in living cells (Romani, 2011). Moreover, ions of $\mathrm{Mg}^{2+}$ may work as the intracellular second messengers (Li et al., 2011). Up to date, however, there have not been findings of MIE except for the enzyme synthesis of ATP in the above cited papers (Buchachenko, et al., 2005, 2008, 2011). The similar MIE of ${ }^{25} \mathrm{Mg}$ is assumed to be in our experiments. Indeed, adaptation of cells to novel growth conditions requires a large variety of stress proteins to be synthesized and ATP, as the main source of energy in microbial cells, is most likely to be the limiting substrate for the adaptation metabolic processes. Similarly, a large variety of biosynthesis is required for recovery of cells from radiation injuries. It is reasonable to suggest that the kinetics of post-radiation recovery is also limited by spin-selective synthesis of ATP as the "bottle-neck". The post-radiation recovery proceeds with higher rate when the cell nanoreactors run on the magnetic isotope of magnesium, because the nuclear spin of $25 \mathrm{Mg}$ catalyzes the ATP synthesis, hereby supplying the cells with more amount of ATP.

The lower level of superoxide dismutase (SOD) activity in the E. coli cells enriched with ${ }^{25} \mathrm{Mg}$, by about 40 per cent when compared to the cells that were grown on nonmagnetic ${ }^{24} \mathrm{Mg}$ (Bogatyrenko et al., 2009a,b), can be also flow from the beneficial effect of the magnetic isotope on the ATP synthesis. The cell nanoreactors of oxidative phosphorylation have very ancient evolutionary origin and, hence, seem to be ones of the most reliable biomolecular machines. But yet their reliability ("robustness") characteristics are not perfect because these molecular machines experience conformational fluctuations (Grodzinsky et al., 1987; Koltover, 1997). It is well known that normal elementary acts of electron transfer on the electron transport chains, be it mitochondria or prokaryotes, alternate with random malfunctions when an electron, rather than waits for transport to the next enzyme of the electron-transport chain, goes directly to an adjacent oxygen molecule. Such an electron leakage results in production of $\mathrm{O}_{2}{ }^{\bullet-}$. Chemical products of $\mathrm{O}_{2} \bullet-$, the so-called reactive oxygen species (ROS), are toxic and initiate free-radical damages in the biopolymer nanoreactors (see, e.g., Chance et al., 1979; Koltover, 2009, 2010a). SOD catalyzes the reaction of dismutation of $\mathrm{O}_{2} \bullet-$ into hydrogen peroxide $\left(\mathrm{H}_{2} \mathrm{O}_{2}\right)$ and oxygen, thus protecting cell structures from $\mathrm{O}_{2} \bullet-$ and its toxic chemical products. It makes its defense "job" in cooperation with two other specific enzymes, catalase and glutathione peroxidase, which catalyze decomposition of $\mathrm{H}_{2} \mathrm{O}_{2}$ into nontoxic reagents, namely $\mathrm{H}_{2} \mathrm{O}$ and $\mathrm{O}_{2}$ (see, e.g., Nelson \& Cox, 2008, and references therein).

As a rule, the level of the SOD activity is adjusted to the intracellular level of $\mathrm{O}_{2}{ }^{\bullet-}$. If SOD activity decreases or increases, it normally reflects the relevant decrease or increase in the production of $\mathrm{O}_{2}{ }^{\bullet-}$ as faulty by-products of the electron-transport nanoreactors of oxidative phosphorylation (Imlay \& Fridovich, 1991; Koltover, 2010a, 2010b, 2011). Hence, the lower level of SOD activity testifies the lower production of $\mathrm{O}_{2}{ }^{\bullet-}$ in the case when the cells are supplied with the magnetic isotope. As cited above, oxidative phosphorylation of ADP proceeds faster with ${ }^{25} \mathrm{Mg}$ by comparison with ${ }^{24} \mathrm{Mg}$ (Buchachenko et al., 2005). Since ${ }^{25 \mathrm{Mg}}$ is more effective cofactor of oxidative phosphorylation, it transpires that the ATP synthase operates faster with the magnetic magnesium nucleus by comparison with the nonmagnetic ones. Meanwhile, under normal coupled conditions, the electron transport is subjected to the "backpressure" of the respiration-generated transmembrane electrochemical $\mathrm{H}^{+}-$ gradient. The partial dissipating of this gradient via the acceleration of ADP 
phosphorylation has been shown to result in the decreased production of $\mathrm{O}_{2} \bullet-$ (see, e.g., Mailloux et al., 2011). Hence, the higher rate of oxidative phosphorylation with magnetic ${ }^{25} \mathrm{Mg}$, in comparison with nonmagnetic ${ }^{24} \mathrm{Mg}$, through the reduction of the $\mathrm{H}^{+}$-gradient "backpressure" should decrease the false electron leakage onto oxygen, thereby reducing the yield of free radicals $\mathrm{O}_{2}{ }^{\bullet-}$ as by-products of the electron transport.

From the point of view of chemical kinetics, with decrease in the rate of oxidative phosphorylation, there is the retardation of electron transport in the sites of the electrontransport chains which are coupled with phosphorylation of ADP. Inasmuch as the input of electron-transport nanoreactors becomes overflowed with electrons ("electron-transport jam"), the probability of electron leakage on oxygen increases. The more is acceleration of the ATP synthesis, the less is probability of the "jam". Hence, the yield of $\mathrm{O}_{2}^{\bullet-}$ as the byproducts of electron transport is bound to be much lower with ${ }^{25} \mathrm{Mg}$-ADP by comparison with ${ }^{24} \mathrm{Mg}$-ADP or ${ }^{26} \mathrm{Mg}$-ADP.

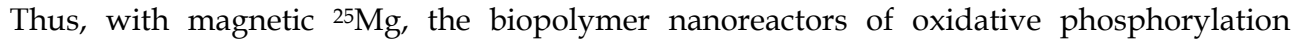
operate not only more effective but more reliable too, in comparison with their operation on non-magnetic isotopes ${ }^{24} \mathrm{Mg}$ and ${ }^{26} \mathrm{Mg}$. Downgrading production of $\mathrm{O}_{2} \bullet-$, the magnetic isotope of magnesium produces, actually, a beneficial preventive antioxidant effect. This antioxidant effect of the nuclear spin, that ${ }^{25} \mathrm{Mg}$ favors the less production of reactive oxygen species, should obviously increase longevity of the electron-transport nanoreactors. Therefore, it can reveal itself in nature as the kinetic nuclear-spin selection of the favorable isotope, namely, the kinetic isotope enrichment with magnetic ${ }^{25} \mathrm{Mg}$ in the processes of recycling and regeneration of the electron-transport nanoreactors. For example, one can expect for the enrichment with the favorable magnetic ${ }^{25 \mathrm{Mg}}$ in recycling and regeneration of cell mitochondria with aging of the cells (Koltover, 2007, 2010b).

Contrary, in the case of photosynthetic nanoreactors, one can predict undesirable prooxidant effect of the magnetic nucleus of ${ }^{25} \mathrm{Mg}$. Indeed, it is known that the function of the vast majority of chlorophyll molecules (Chl), as the derivatives of the magnesiumprotoporphyrin complexes, is to absorb light energy and transfer it to the specific energy sinks, the so-called reaction centers of the photosynthetic nanoreactors (Nelson \& Cox, 2008). While performing this energy-transfer function, the light-exited $\mathrm{Chl}$ molecules are in the singlet state $\left({ }^{1} \mathrm{Chl}^{*}\right.$, electron spin $\left.S=0\right)$. However, there is probability of the radiationless relaxation into the triplet state $\left({ }^{3} \mathrm{Chl}, S=1\right)$ followed by formation of singlet oxygen, ${ }^{1} \mathrm{O}_{2}$, the molecules of which are substantially more reactive by comparison with usual triplet $\mathrm{O}_{2}$ molecules and, thereafter, produce oxidative damages. As nuclear spin of $25 \mathrm{Mg}$ can catalyze the conversion of ${ }^{1} \mathrm{Chl}^{*}$ into the triplet ${ }^{3} \mathrm{Chl}$, one can expect for the higher yield of ${ }^{1} \mathrm{O}_{2}$ and, thereafter, more photodynamic damages in the cells with the chlorophyll molecules containing ${ }^{25} \mathrm{Mg}$ instead of the spinless ${ }^{24} \mathrm{Mg}$ or ${ }^{26} \mathrm{Mg}$. Correspondingly, it is beyond reason to hope for selection of the magnetic ${ }^{25} \mathrm{Mg}$, in the case of algae or green plants. Besides, the functional disadvantage of ${ }^{25} \mathrm{Mg}$ should be followed by increased synthesis of carotenoids and other natural antioxidants. Indeed, measurements of magnesium isotopic composition of the chlorophylls extracted from cyanobacteria and similar analysis of the chlorophyll forms in the leaves of English Ivy (Hedera helix L.) have revealed the isotope distribution following usual classical mass-isotope effect with no evidence for depletion or enrichment of ${ }^{25} \mathrm{Mg}$ (Black et al., 2007). 
Apart from magnesium, there are many other elements which have both kind of stable isotopes, nonmagnetic and magnetic ones, amongst them - carbon, oxygen, calcium, iron and zinc (see Table 1). In passing, nuclear spin of ${ }^{17} \mathrm{O}$ should lift the spin ban over the reaction of the mitochondrial ubisemiquinone radicals with oxygen (see Fig. 1c), thereby catalyzing formation of $\mathrm{O}_{2} \bullet-$. As a result, one can expect for more reactive oxygen radicals and more free-radical damages due to ${ }^{17} \mathrm{O}$ in comparison with nonmagnetic ${ }^{16} \mathrm{O}$ and ${ }^{18} \mathrm{O}$. The pro-oxidant action of ${ }^{17} \mathrm{O}$ can reveal itself as the selective enrichment of free-radical peroxidation products with this unfavorable magnetic isotope as compared with ordinary metabolites.

\section{Conclusions and outlook}

Factual evidence of magnetic isotope effect, on its own, indicates that the "bottle-neck" of the process under investigation is a free-radical or ion-radical reaction. Within the scope of free radical research, MIE can serve as the unique indicator to elucidate if the reaction under study proceeds through a free-radical or ion-radical pair as the key operand of the reaction.

Up to date, however, there have been no efforts to detect magnetic-isotope effects for other elements, except magnesium, in biopolymer nanoreactors.

Our experimental data have documented, for the first time, the beneficial magnetic-isotope effects of ${ }^{25} \mathrm{Mg}$ in vivo. Although the detailed mechanisms of the ability of the living cell to perceive magnetic properties of the atomic nuclei require further investigations, the "nuclear spin catalysis", as such, always and unambiguously indicates that the reaction under study is a spin-selective process with participation of paramagnetic intermediates, such as free radical pair, ion-radical pair or triplet state that undergo the spin conversion. Along this line the general principles of spin chemistry, amongst them - control of biochemical reactivity in living cells by the selective modification with stable magnetic isotopes, hold considerable promise. In part, the preventive antioxidant effect of $25 \mathrm{Mg}$ opens the ways toward the novel biomedicine of anti-stress anti-aging drugs enriched with the magnetic-isotopes. The discovery of the magnetic-isotope effect in radiation biology opens up the way to the development of novel radio-protectors, based on the magnetic isotopy. Furthermore, inasmuch as the electron and nuclear spin moments can be changed by external magnetic fields, it makes possible to exert control over efficiency and reliability of biomolecular nanoreactors with the help of relevant magnetic and electromagnetic fields.

\section{Acknowledgments}

Financial support from Russian Foundation for Basic Research, projects no. 10-03-01203a and 10-04-90408-Ukr_a, is greatly acknowledged. I am grateful to L.V. Avdeeva-Tumanova, T.N. Bogatyrenko, \& E.A. Kudryashova (Institute of Problems of Chemical Physics, RAS, Chernogolovka, Moscow Region), V.L. Berdinsky, D.G. Deryabin, E.A. Royba, \& U.G. Shevchenko (Orenburg State University, Orenburg), T.A. Evstykhina \& V.G. Korolev (SaintPetersburg Institute of Nuclear Physics, RAS, Gatchina, Leningrad Region), and D.M. Grodzinsky \& Y.A. Kutlakhmedov (Institute of Cell Biology and Genetic Engineering, Ukraine Academy of Sciences, Kyiv, Ukraine) for their fruitful collaboration. I am especially appreciated to Kathryn S. Tarasevich-Laukhina for her excellent assistance at the very beginning of this work. 


\section{References}

Black, J.R., Yin, Q., Rustad, J.R., \& Casey, W.H. (2007). Magnesium-isotopic equilibrium in chlorophylls. J. Am. Chem. Soc., Vol. 129, 8690-8691.

Blumenfeld, L.A., \& Koltover, V.K. (1972). Energy transformation and conformational transitions in mitochondrial membranes as relaxation processes. Mol. Biol. (Moscow), Vol. 6, 161-166.

Bogatyrenko, T.N., Kudryashova, E.A., Tumanova, L.V., \& Koltover, V.K. (2009a). Influence of different isotopes of magnesium on SOD activity level in the study of kinetics of growth of E. coli. Proceedings of the V International congress on Low and Superlow Fields and Radiations in Biology and Medicine, Saint-Petersburg, 29.06.2009-03.07.2009, p. 92.

Bogatyrenko, T.N., Kudryashova, E.A., Shevchenko, U.G., Tumanova, L.V., \& Koltover, V.K. (2009b). Stable isotope of magnesium-25 as micronutrient Antioxidant. Proceedings of the $3^{\text {rd }}$ international conference on Nutrition, Oxygen Biology and Medicine, Paris, 8-10 April, 2009, p. 57.

Brocklenhurst, B. (2002) Magnetic fields and radical reactions: recent developments and their role in nature. Chem. Soc. Rev., Vol. 31, 301-311.

Buchachenko, A.L. (2009). Magnetic Isotope Effect in Chemistry and Biochemistry, Nova Science Publishing, New York.

Buchachenko, A.L., Kouznetsov, D.A., Arkhangelsky, S.E., Orlova, M.A., \& Markarian, A.A. (2005). Spin biochemistry: magnetic ${ }^{24} \mathrm{Mg}-25 \mathrm{Mg}-26 \mathrm{Mg}$ isotope effect in mitochondrial ADP phosphorylation. Cell Biochem. Biophysics, Vol. 43, 243-252.

Buchachenko, A. L., Kouznetsov, D.A., Arkhangelsky, S.E., Orlova, M.A., \& Markaryan, A.A. (2005). Magnetic isotope effect of magnesium in phosphoglycerate kinase phosphorylation. Proc. Natl. Acad. Sci. USA, Vol. 102, 10793-10796.

Buchachenko, A.L., Kouznetsov, D.A., Breslavskaya, N. N., \& Orlova, M.A. (2008). Magnesium isotope effects in enzymatic phosphorylation. J. Phys. Chem. B, Vol. 112, 2548-2556.

Buchachenko, A.L., Kouznetsov, D.A., Breslavskaya, N. N., Shchegoleva, L.N., \& Arkhangelsky, S.E. (2011). Calcium induced ATP synthesis: Isotope effect, magnetic parameters and mechanism. Chem. Phys. Lett., Vol. 505, 130-134.

Chance, B., Sies, H., \& Boveris, A. (1979). Hydroperoxide metabolism in mammalian organs. Physiol. Rev., Vol. 59, 527-605.

Coudray, Ch., Feillet-Coudray, Ch., Rambeau, M., Tressol, J.C., Gueux, E., Mazur, A., \& Rayssiguier, Y. (2006). The effect of aging on intestinal absorption and status of calcium, magnesium, zinc, and copper in rats: A stable isotope study. J. Trace Elem. Med. Biol., Vol. 20, 73-81.

Fredens, J., Engholm-Keller, K., Giessing, A., Pultz, D., Larsen, M. R., Højrup, P., MøllerJensen, J., \& Færgeman, N.J. (2011). Quantitative proteomics by amino acid labeling in C. elegans. Nature Methods, Vol. 8, 845-847.

Gould, J.L. (2010). Magnetoreception. Current Biol., Vol. 20, R431-R435.

Grant, D.M. \& Harris, R.K. (Eds.). (1996). Encyclopedia of Nuclear Magnetic Resonance, Wiley, Chichester.

Grodzinsky, D.M., Evstyukhina, T.A., Koltover, V.K., Korolev, V.G., \& Kutlakhmedov, Y.A. (2011). Effect of the magnetic isotope of magnesium, ${ }^{25} \mathrm{Mg}$, on post-radiation recovery of Saccharomyces cerevisiae. Proceedings of National Academy of Sciences of Ukraine, No. 12 153-156. 
Grodzinsky, D.M., Vojtenko, V.P., Kutlakhmedov, Y.A., \& Koltover, V.K. (1987). Reliability and Aging of Biological Systems, Naukova Dumka, Kiev. 172 P.-book in Russ.

Hill, S., Hirano, K., Shmanai, V.V., Marbois, B.N., Vidovic, D., Bekish, A.V., Kay, B., Tse, V., Fine, J., Clarke, C.F., \& Shchepinov, M.S. (2011). Isotope-reinforced polyunsaturated fatty acids protect yeast cells from oxidative stress. Free. Radical Biol. Med., Vol. 50, 130-138.

Imlay, J.A., Fridovich, I. (1991). Assay of metabolic superoxide production in Escherichia coli. J. Biol. Chem., Vol. 266, 6957-6965.

Koltover, V.K. (1997). Reliability concept as a trend in biophysics of aging. J. Theor. Biol., Vol. $184,157-163$.

Koltover, V.K. (2007). Antioxidant and prooxidant effects of magnetic isotopes in biomolecular nanoreactors. Free Radic. Biol. Med., Vol. 43, S. 67-68.

Koltover, V.K. (2008). Nuclear spin catalysis in free-radical biology: antioxidant effects of magnesium-25. Free Radic. Biol. Med., Vol. 45, S. 12.

Koltover, V.K. (2009). Bioantioxidants: The systems reliability standpoint. Toxicology and Industrial Health, Vol. 25, No. 4-5, 295-299.

Koltover, V.K. (2010a). Antioxidant biomedicine: from free radical chemistry to systems biology mechanisms. Russian Chemical Bulletin, Vol. 59, No. 1, 37-42.

Koltover, V.K. (2010b). Reliability in nanoengineering: Nuclear spin of magnesium-25 as reliability factor in molecular and biomolecular nanoreactors. Nanotechnology 2010, Vol. 3, pp. 475-477, ISBN: 978-1-4398-3415-2, Danville (CA, USA): Nano Science and Technology Institute.

Kol'tover, V.K. (2011). Reliability of electron-transport membranes and the role of oxygen radical anions in aging: stochastic modulation of the genetic program. Biophysics, Vol. 56, No. 1, 125-128.

Kol'tover, V.K., Kutlakhmedov, Y.A., \& Afanaseva, E.L. (1980). Recovery of cells from radiation-induced damages in the presence of antioxidants and the reliability of biological systems. Doklady Biophysics, Vol. 254, 159-161.

Koltover, V.K., Reichman, L.M., Yasajtis, A.A., \& Blumenfeld, L.A. (1971). A study of spinprobe solubility in mitochondrial membranes correlated with ATP-dependent conformation changes. Biochim. et Biophys. Acta, Vol. 234, 296-310.

Koltover, V.K., Shevchenko, U.G., Avdeeva, L.V., Royba, E.A., Berdinsky, V.L., \& Kudryashova, E.A. (2012). Magnetic isotope effect of magnesium in the living cell. Doklady Biochemistry and Biophysics, Vol. 442, No. 1-2, 12-14.

Komeili, A. (2007). Molecular mechanisms of magnetosome formation. Annual Review of Biochemistry, Vol. 76, 351-366.

Larance, M., Bailly, A.P., Pourkarimi, E., Hay, R.T., Buchanan, G., Coulthurst, S., Xirodimas, D.P., Gartner, A., \& Lamond, A.I. (2011). Stable-isotope labeling with amino acids in nematodes. Nature Methods, Vol. 8, 849-851.

Li, F.Y., Chaigne-Delalande, B., Kanellopoulou, C., Davis, J.C. H. F., Douek, M.D.C., Cohen, J.I., Uzel, G., Su, H.C., \& Lenardo, M.J. (2011). Second messenger role for $\mathrm{Mg}^{2+}$ revealed by human T-cell immunodeficiency. Nature, Vol. 475, 471-476.

Lohmann, K.J. (2010). Magnetic-field perception. Nature, Vol. 464, 1140-1142.

Mailloux, R J., Harper, M.-E. (2011). Uncoupling proteins and the control of mitochondrial reactive oxygen species production. Free Radic. Biol. Med., Vol. 51, 1106-1115. 
Nelson, D.L. \& Cox, M.M. (2008). Lehninger Principles of Biochemistry, W.H. Freeman, New York.

Nohl, H., Koltover, V., \& Stolze, K. (1993). Ischemia/reperfusion impairs mitochondrial energy conservation and triggers $\mathrm{O}_{2}{ }^{*}-$ release as a by-product of respiration. Free Radical Research, Vol. 3, No. 18, 127-137.

Novick, A., Szilard, L. (1949). Experiments on light-reactivation of ultra-violet inactivated bacteria. Proc. Natl. Acad. Sci. USA, Vol. 35, 591-600.

Romani, A.M.P. (2011). Cellular magnesium homeostasis. Arch. Biochem. Biophys., Vol. 512, 123.

Weatherall, A., Proe, M.F., Craig, J., Cameron, A.D., \& Midwood, A.J. (2006). Internal cycling of nitrogen, potassium and magnesium in young Sitka spruce. Tree Physiol., Vol. 26, 673-680. 


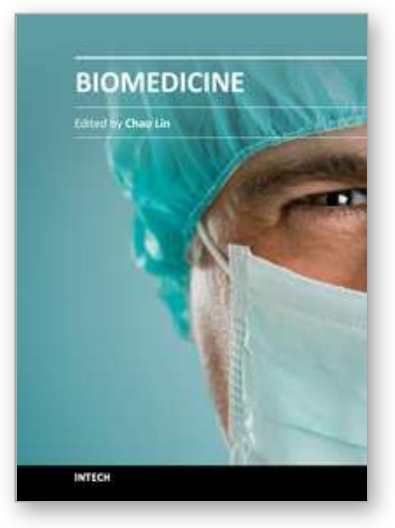

\author{
Biomedicine \\ Edited by Dr. Chao Lin
}

ISBN 978-953-51-0352-3

Hard cover, 200 pages

Publisher InTech

Published online 21, March, 2012

Published in print edition March, 2012

Comprehensive and systematic scientific researches in cell biology and molecular biology have promoted the evolution of traditional medicine. Scientists are now able to interpret a few perplexed medical difficulties with the emphasis on molecular levels. This book focuses on frontier progress in modern biomedical science dealing with regenerative medicine, gene medicine, nanobiomedicine, and medical devices. Each chapter is intently chosen and written by professional experts in the field of biomedical science. Biomedicine is a valuable guide for the readers to become aware of current advancement in rapidly moving field of biomedicine.

\title{
How to reference
}

In order to correctly reference this scholarly work, feel free to copy and paste the following:

Vitaly K. Koltover (2012). Stable Magnetic Isotopes as a New Trend in Biomedicine, Biomedicine, Dr. Chao Lin (Ed.), ISBN: 978-953-51-0352-3, InTech, Available from:

http://www.intechopen.com/books/biomedicine/stable-magnetic-isotopes-as-a-new-trend-in-biomedicine

\section{INTECH}

open science | open minds

\section{InTech Europe}

University Campus STeP Ri

Slavka Krautzeka 83/A

51000 Rijeka, Croatia

Phone: +385 (51) 770447

Fax: +385 (51) 686166

www.intechopen.com

\section{InTech China}

Unit 405, Office Block, Hotel Equatorial Shanghai

No.65, Yan An Road (West), Shanghai, 200040, China 中国上海市延安西路65号上海国际贵都大饭店办公楼405单元

Phone: +86-21-62489820

Fax: +86-21-62489821 
(C) 2012 The Author(s). Licensee IntechOpen. This is an open access article distributed under the terms of the Creative Commons Attribution 3.0 License, which permits unrestricted use, distribution, and reproduction in any medium, provided the original work is properly cited. 